\title{
Students' Trends in Islamic Communication Postgraduate in 2010-2016 State Islamic University of North Sumatera (UINSU)
}

\author{
Anang Anas Azhar ${ }^{1}$, Ahmad Tamrin Sikumbang ${ }^{2}$ \\ ${ }^{1}$ Faculty of Social Science, UIN North Sumatera \\ ${ }^{2}$ Faculty of Da'wah and Communication, UIN North Sumatera \\ anang_mb76@yahoo.com
}

\begin{abstract}
This article aims to discuss the tendency of specialization of students of the Islamic communication study program at the Postgraduate Program of the State University of North Sumatra in 2010-2016, mapping the various kinds of tendencies and interests of UINSU Islamic communication and broadcasting students. By looking at various trends of interest that exist. All of them were obtained from observations of students and graduation of UINSU Islamic broadcasting communication. This research relies on field study methods and library research, conducted at the Islamic University of North Sumatra (UINSU). The data found from the study of academics include: 1.) As an implication of the tendency of students who have graduated from the undergraduate education program to the postgraduate level to choose the same study program as in the Islamic communication and broadcasting study program at UIN North Sumatra, then that also along with the high numbers that affect the motivation of strata 1 to return to study and continue their education at a higher level. This condition is caused by learning motivation can grow because of the need for what is learned, both for the present and the future. That someone who has intrinsic motivation always wants to advance in learning. This desire is motivated by positive thinking, that everything learned at the strata-level will be needed and very useful now and in the future. 2.) The interest of the community is increasing to choose the Islamic broadcasting communication department as the chosen study program to continue the study, considering that the administrative conditions are relatively easy and do not make students who continue their studies happy and fast in completing their studies, it does not mean that the graduates with the state of administration and graduates graduating on time.
\end{abstract}

Keywords: postgraduate uinsu, trend, motivation, interest

\section{Introduction}

The interest of the community to enter university recently has become one of the main attractions for our society. The desire of the community to enter college can be seen in terms of the quantity of prospective students who enroll. The number of students who enroll, it turns out is not fully acceptable, especially universities that hold the status of the country because it has been pegged using a quota system set by the government. The amount received was found to be less, when compared to the number of registrants in the amount of tens of thousands or even hundreds of thousands to enter the state universities.

Today, to get a better guarantee of the future, it is not enough to just graduate and rely on an S1 diploma. Surveys from job vacancies offered to the public are more widespread because most require graduates who are accepted to work to be graduates of S1 or S2. In particular S1 graduates, for now they cannot teach anymore in higher education because the 
government requires a lecturer to teach at a tertiary level of education at least S2 education. More specifically in the Islamic field of focus that is developed in Islamic universities. ${ }^{1}$

The Islamic Communication Study Program S2 and S3 is an alternative choice for prospective UIN North Sumatra postgraduate students. Initially, the opening of this study program was not called Islamic communication but rather the development of Islamic society in 2000. However, due to several requests, the study program finally changed its name to Islamic Communication Study Program and officially opened the 2003 Islamic Communication Study Program. this is quite a lot. Because, the tendency of specialization in this study program was motivated by the alumni of the da'wah faculty. Alignment of da'wah science and communication makes this study program tends to be in demand. Another background is why the tendency of this study program is sought, because of the character of the teaching staff, even more important is the alumni's output to work. The jobs displayed in a number of brochures from the study program have a market share of employment from alumni. Another issue is the tendency why the Da'wah and Communication Faculty alumni tend to choose this study program, because it is in harmony with the Islamic Communication and Broadcasting study program at UINSU S1 FDK.

Along with the operational journey of the Islamic Communication Study Program S2, the number of students entering the study program has experienced an ups and downs. This is evidenced by the number of first year students over 20, but in the following years it tends to decline. There is a tendency to decrease the interest of prospective students to choose the study program, related to the output of the alumni. In fact, if viewed from the vision of the formation of this study program, there are central points of excellence in education, study, research and development of communication science at the master level. ${ }^{2}$

While the purpose of the study program is to produce master's degree graduates who are capable of developing communication sciences. Print researchers in the field of communication science, while giving birth to teaching staff who have extensive knowledge and insight in the field of communication science. Even though the vision, mission and objectives of the study program have been disseminated, the development of the Islamic Communication study program has not yet run optimally when viewed in terms of the quantity of students. However, the course of study program should not stop, even graduates produced from this study program have spread to a number of agencies, ranging from lecturers, communication practitioners, journalists and extension agents. The tendency of specialization of this study program, although not much, but the operational operations continue until finally BAN PT establishes the accreditation of Islamic Communication study programs at the $\mathrm{S} 2$ level to obtain $\mathrm{B}$.

\section{Review of Literature}

The tendency in Indonesian has the meaning of desire (liking). The tendency can be interpreted as the beginning of experimenting and solving problems with their own abilities. Tendency is something that has the nature or attitude which is desire, passion, will, desire, liking, intention, predisposition, tendency to something and other aspects. ${ }^{3}$

\footnotetext{
${ }^{1}$ Hasan Asari, Abstraksi Postgraduate Thesis State Islamic Institute (IAIN) of North Sumatera, (Medan : 2009) p. 6

2 Ibid : p. 12

${ }^{3}$ WJS Poerwadarminta, Kamus Besar Bahasa Indonesia (KKBI), Jakarta, 2008, p. 145
} 
Tendencies can grow when a person watches them little by little even at the same time. The tendency to be born of information that enters consciously or unconsciously towards the habit is like the example of a small child who always watches action films and when he grows up he wants to become a martial arts expert, or a young man who watches politics and when he turns 25 he wants politics. ${ }^{4}$

The issue according to Barry Jones \& Chase is an unsolved issue that is ready to be made a decision. Issues represent a gap between corporate practice and the expectations of stakeholders. Based on the aforementioned definition, the issue is something that occurs both inside and outside the organization which if not handled properly will have a negative effect on the organization and continue in the crisis phase. Issues including information that can be easily obtained in the informatics era like this, sometimes true information can also be said to be an issue because freedom of aspiration is at its peak, information that is considered an issue can also be said to be fact if the issue is conveyed gradually and long term . If this is done, the issue can be born as a fact among the people. The tendency of issues is the condition in which a habitat or community consumes raw information and that information can lead to negative impacts.

The tendency of intentional issues is that information is carried out continuously and is more likely to be negative and memorable to bring down one of the parties. The tendency of issues is easily accepted in social media and mass media. The issue tendency is easily trusted by the public. The tendency for the issue to be easily made and the impact of it back to the community itself, and the longer the duration of the issue is made into the topic of conversation, the issue will be considered a fact. ${ }^{5}$

Humans from birth have been given something by God perfection. The completeness that has been given to humans since birth is one of them is talent. Talent is an advantage that has been given to humans since the womb. If you succeed in arousing his talent, and succeed in exploring the excess advantages that God has given him, he will be a lucky person.

In Indonesian Language Dictionary (KKBI), interest means a tendency of a high heart to something, also interpreted as passion or desire. Whereas in English, interest is often described by the words "interest" or "passion". Interest means a feeling of wanting to pay attention to and curious about something, while "passion" has the same meaning as passion or a strong feeling or enthusiasm for an object. ${ }^{6}$

In simple terms, interest can be interpreted as a tendency to give attention and act to people, activities or situations that become the object of that interest accompanied by feelings of pleasure. Within these limits contained an understanding that in interest there is concentration of the subject's attention, there is an effort (to approach / know / have / master / relate) of the subject that is done with a feeling of pleasure, there is attraction from the object. $^{7}$

According to Stiggins states that interest is one dimension of affective aspects that play a lot in a person's life. The affective aspect is the aspect that identifies the dimensions of feeling from emotional awareness, disposition, and will that influence one's thoughts and actions. This affective dimension includes three important things, namely (1) relating to feelings about different objects; (2) those feelings have a direction starting from the neutral

\footnotetext{
${ }^{4}$ Ibid : h. 127

${ }^{5}$ Imam B Jauhari, Teori Sosial, Proses Islamisasi Dalam Sistem Ilmu Pengetahuan, Pustaka Pelajar, 2012

${ }^{6}$ Andin Sefrina, Deteksi Minat, p. 27.

${ }^{7}$ Abdul Rahman Shaleh dan Muhbib Abdul Wahab, Psikologi Suatu Pengantar, Ibid, p. 263.
} 
point to the opposite side, not positive and not negative; (3) various feelings that have different intensities, from strong to weak. Aiken revealed the definition of interest as a preference for activities beyond other activities. This means that interest is related to values that make someone have a choice in their life

Hurlock argues that interest is a source of motivation that encourages people to do something they want if they are free to choose. When they see that something is profitable, they feel interested. This then brings satisfaction. When satisfaction decreases, interest decreases.

Motivation is a condition that is contained in someone who encourages to do a certain activity in order to achieve a goal. All mental activities that are felt / experienced that provide conditions so that the occurrence of these behaviors is called a motive. ${ }^{8}$

\section{Methodology}

This study was designed as a qualitative descriptive study, because the focus of the research was on observation and interviews. Research like this, also called qualitative research, because this research seeks to understand the object being studied as it is, is not manipulated but is understood through analysis after the data is obtained. ${ }^{9}$ According to Creswell, as quoted by Basuki, that qualitative research is a research process to understand human or social problems by creating a comprehensive and complex picture presented with words, reporting detailed views obtained from the sources of information, and done in background (setting ) natural.

Meanwhile, descriptive research is a form of research aimed at describing or describing existing phenomena, both natural phenomena and human engineering. The purpose of descriptive research is to make a systematic, factual, and accurate enunciation of the facts and nature of a particular population or area. This study was used to find out how the development of the interest of postgraduate students in Islamic communication at UIN North Sumatra. ${ }^{10}$

The approach used is descriptive analysis approach, because the tendency of specialization is included in the concentration of psychology studies. The tendency is a form of non-verbal communication by a person or institution, to influence the behavior, thoughts, views, and opinions of others about what is in demand. Qualitative research is also often dubbed the scientific method, therefore qualitative research is often also said to be natural inquiry. Researchers are not obliged to form certain conceptions or theories, especially regarding the aspects studied. ${ }^{11}$ This research was conducted in the Islamic Communication Studies Program Postgraduate of the State Islamic University of North Sumatra (UINSU) Medan Jalan Sutomu Ujung No. 1 Medan. While the research was conducted for three months.

\footnotetext{
${ }^{8}$ Bambang Widiatmodjo, Psikologi Umum, Diktat Perkuliahan, not published, IAIN

${ }^{9}$ Mulyana, Metode Penelitian, p. 157-159.

${ }^{10}$ Heru Basuki, Penelitian kualitatif: Untuk Ilmu-Ilmu Kemanusiaan dan Budaya (Jakarta: Universitas Gunadarma, 2006), p. 86.

${ }^{11}$ Kholil, Syukur, Metodologi Penelitian Komunikasi, Cipta Pustaka Media, 2006, p. 121.
} 


\section{Result and Discussion \\ 4.1 Students' Trends in Islamic Communication Postgraduate In 2010-2016 State Islamic University of North Sumatera (Uinsu)}

The tendency in Indonesian has the meaning of desire (liking). The tendency can be interpreted as the beginning of experimenting and solving problems with their own abilities. Tendency is something that has the nature or attitude which is desire, passion, will, desire, liking, intention, predisposition, tendency to something and other aspects. ${ }^{12}$

Continuing education to higher education in the present has become a necessity for many people, because by continuing higher education one will gain broader knowledge and experience. However, without an interest someone will not try to choose to explore knowledge at a higher level as well as postgraduate and the selection of the same study program or choose a cross study program. In other words, if someone is not interested or has an interest in continuing to graduate education with the same college or study program that is the same or different in terms of both, they have chosen to settle in their knowledge and usually only focus on their work, especially if there are no demands on him in work issues that make him have to really continue his education to graduate level. Someone who is very interested in continuing their education after graduating from the Undergraduate level will usually choose to continue their education in accordance with the specialization they have previously, especially for students of the UIN North Sumatra postgraduate program.

As an implication of the tendency of students who have graduated from the undergraduate education program to the postgraduate level to choose the same study program as in the Islamic communication and broadcasting study program at UIN North Sumatra, then this is also in line with the high number of levels affecting motivation to study. and continuing education at a higher level. This condition is caused by learning motivation can grow because of the need for what is learned, both for the present and the future. That someone has Intrinsic motivation always wants to advance in learning. This desire is motivated by positive thinking, that everything learned at the strata-level will be needed and very useful now and in the future. ${ }^{13}$

For this reason, it is not surprising that the students who have completed their studies in the study program of communication and Islamic broadcasting in UIN North Sumatra are competing to get the opportunity to obtain seats at the postgraduate level. Get a seat that they dream of in hopes of gaining knowledge and knowledge in the field that makes them more likely to succeed in getting decent jobs after they graduate. In addition to the influence of the presumption of the community as if it required the need for a diploma more than a bachelor's degree as a condition for obtaining decent work in accordance with its standards, let's say being a lecturer for example. There are other influences that can influence the tendency of elections to continue their education, one of which is originating from internal learning motivation. ${ }^{14}$

The variety of learning motivation and interest of students to continue their education to the postgraduate level can be related to the theory of motivation that arises because of the

\footnotetext{
${ }^{12}$ WJS Poerwadarminta, Kamus Besar Bahasa Indonesia (KKBI), Jakarta, 2008, h. 145

${ }^{13}$ Forum Group Discussion delivered by Erwan Efendi as Alumni of Islamic communication and broadcasting (27 August 2018)

${ }^{14}$ Forum Group Discussion delivered by. Erwan Efendi as Alumni of Islamic communication and broadcasting (27 August 2018)
} 
need for what they learn, so it can be assumed that students who have high interest will certainly be more motivated in learning and choose to continue their studies. ${ }^{15}$

Tendency is a psychological factor that influences a person's actions. In all humans, the tendency to play an important role in one's life and has a very large impact on the determination of behavior and attitudes. An ordinary person becomes lazy, reluctant to do something when he does not choose or desire to do these activities. The importance of tendencies in humans is because tendencies can determine a form of human behavior in addition to negative behavior, but tendencies can also have positive effects such as desires and desires that tend to be strong to choose to pursue postgraduate education at UIN North Sumatra, tendency is a strong source of motivation, and become a driving factor for doing something. ${ }^{16}$

\subsection{Students' Interest in Islamic Communication Postgraduate In 2010-2016 State Islamic University of North Sumatera (UINSU)}

In Indonesian Language Dictionary (KKBI), interest means a tendency of a high heart to something, also interpreted as passion or desire. Whereas in English, interest is often described by the words "interest" or "passion". Interest means a feeling of wanting to pay attention to and curious about something, while "passion" has the same meaning as passion or a strong feeling or enthusiasm for an object. ${ }^{17}$

In simple terms, interest can be interpreted as a tendency to give attention and act to people, activities or situations that become the object of that interest accompanied by feelings of pleasure. Within these limits contained an understanding that in interest there is concentration of the subject's attention, there is an effort (to approach / know / have / master / relate) of the subject that is done with a feeling of pleasure, there is attraction from the object. $^{18}$

Great interest has an effect on learning, because if the material learned is not in accordance with the interests of students will not learn as well as possible, because there is no attraction. He was reluctant to learn he did not get satisfaction from the lesson. Learning material that attracts students' interest is easier to learn and save, because interest in luring students to be more active in learning even continues to higher study programs.

If marginalized, Islamic Broadcasting becomes Islamic Broadcasting which means broadcasting Islam on radio, television, and film as well as the internet or Islamic broadcasting institutions (radio, TV, and propaganda films). Based on the KPI curriculum, students study or explore two things: Islam and Communication, which is to explore the Islamic religion and the skills to spread Islamic insights through the media, but that does not mean that Islamic broadcasting communication is only focused on Islamic communication studies, but on study programs. It also learns about the science of communication on other public campuses that do not provide Islamic labels.

KPI students not only explore the Koran and Al-Hadith as the two main sources of Islamic teachings, but also learn communication skills, especially journalism and broadcasting. There are also KPI majors which are divided into two study programs. Thus, de jure, KPI alumni not only become experts in Islam, but also master the science of journalism

\footnotetext{
${ }^{15}$ Forum Group Discussion delivered by Hasrat Efendi Samosir (27 August 2018)

${ }^{16}$ Forum Group Discussion delivered by Hasrat Efendi Samosir (27 August 2018)

${ }^{17}$ Andin Sefrina, Deteksi Minat, hlm. 27.

${ }^{18}$ Abdul Rahman Shaleh dan Muhbib Abdul Wahab, Psikologi Suatu Pengantar, Ibid, p. 263.
} 
and broadcasting to preach it through various print, electronic, and internet media. Some of the reasons that caused the change of name from Islamic communication to Islamic broadcasting communication were caused by following the name path listed on the Directorate of Higher Education, considering the name of the study program and accreditation registered with the Directorate of Higher Education was communication and broadcasting of Islam not Islamic communication. ${ }^{19}$

Dr.'s response H. Asrad Efendi Samosir regarding the increasing interest of students in the world of academics by choosing the communication study program for Islamic broadcasting postgraduate is that "everything is inseparable from the first factor, which is input factor, in the form of communication alumni from undergraduate or undergraduate programs with study programs similarly, causing the relevance of graduates to enter and connect academically through the UIN North Sumatra postgraduate program, this occurs because there is no detachment of the viewpoints of connection to a more and linear level of education, although some others do not come from the same study program but different study programs at the $S-1$, and among them also come from different campuses such as UNIMED, USU, UMSU, and others.

For communication majors in North Sumatra, postgraduate study programs are in various universities including USU and UMSU, but only the two study programs at this university are general communication science study programs, this is what makes the opportunity for UIN North Sumatra to develop their products through labels owned by communication Islam in it and this also becomes a distinct advantage for the Islamic community. This can be seen from the development of spirituality that occurs in the body of society today. The establishment of Islamic communication has transcendental values that provide happiness that is not only material but also material in nature so it requires Islamic communication majors, and today continues to grow rapidly until the doctoral program emerges, which has students from various regions not only from Sumatra North only, but there are also those who come from Aceh, West Sumatra, Riau, even from Java, so it can be seen that the increase also continues. "For this year 30 people have entered the doctoral program, and that is also one of the which is quite a lot when viewed from the program taken. $^{20}$

As for the various advantages possessed by Islamic communication study programs in addition to material and material values, that is seen from the general view between conventional communication with Islamic communication. As with 1.) Islamic communication there are human and divine values that are owned in it, so not only instilling human values as well as those of conventional communication. 2.) Conventional communication does not fully provide solutions to human life, as in social media today, the public is in dire need of communication ethics, given the hoaxes that have spread, the role of Islamic communication is to be able to provide teaching and values instilled in the community utilize social media as a way of preaching and not spread hoaxes or utterances of slander and hatred. 3.) is religion has given true happiness to the community to run life in accordance with prevailing religious rules and norms so that communication to anyone will also be carried out as gently as possible and of course safeguard ethics. 4.) why enthusiasts

\footnotetext{
${ }^{19}$ Forum Group Discussion delivered by Hasrat Efendi Samosir (27 August 2018)

${ }^{20}$ Forum Group Discussion delivered by Erwan Efendi as Alumni of Islamic communication and broadcasting (27 August 2018)
} 
are increasing, because the cost of education is relatively cheap compared to study programs and campuses in North Sumatra. ${ }^{21}$

\section{Conclusion}

Based on the results of the analysis and discussion of the data, the authors obtained conclusions that can be drawn from the research on the tendency of specialization of students of communication and poetry Islamic study programs in the postgraduate class of North Sumatra Islamic University Medan in 2010-2016, including:

1. The interest of the community is increasing to choose the Islamic broadcasting communication department as the chosen study program to continue the study, considering that the administrative conditions are relatively easy and do not make students who continue their studies happy and fast to complete their studies, does not mean that the graduates are not competent the state of administration and graduates who graduate on time.

2. The advantages possessed by Islamic communication with general or conventional communication study programs which cause an increase in interest of students entering the postgraduate program each year, namely, the cultivation of moral values will not be found in conventional or general communication sciences, Islamic communication is clearly different from such This form, which causes every year the Islamic communication study program to continue to grow and be in demand, is an example of the most basic thing from Islamic communication study programs with conventional communication.

3. Bringing Islamic elements or values to communication that are considered acceptable by the wider community, one of them is "soft in conveying something so that the information or opinions that we convey can be well received by everyone.

4. The state of Indonesia which requires journalists with scientific knowledge that are reliable both public and religious. Marketing said that journalism with an Islamic religion in Indonesia is part of the general national journalism, the decline of journalism which is based on Islam cannot be separated from the backwardness of Indonesian journalism. That is why Muslim journalists as pilots of Islamic journalism are very interesting to talk about because they are based on individual rights and collective responsibility. This also affects the increase in graduates and interest from Islamic broadcasting communication science graduates who see the situation in which people need Muslim journalists.

\section{References}

Abdul Basit, Jurnal: Ilmu Komunikasi Islam Dalam Persefektif Ilmu.

Andin Sefrina, Deteksi Minat.

Bambang Widiatmodjo, Psikologi Umum, Diktat Perkuliahan, Tidak diterbitkan, IAINSunan Ampel Surabaya, 2004, hal. 15

Jalaluddin Rakhmat.1984.Metode Penelitian Komunikasi Dilengkapi Contoh Analisis

Statistik (Bandung: Remaja Rosdakarya)

Mulyana, Metode Penelitian, hlm. 157-159.

\footnotetext{
${ }^{21}$ Forum Group Discussion delivered by Hasrat Efendi Samosir (27 August 2018)
} 
Heru Basuki. 2006. Penelitian kualitatif: Untuk Ilmu-Ilmu Kemanusiaan dan Budaya (Jakarta: Universitas Gunadarma)

Lexy. J. Moleong.2000.Metodologi Penelitian Kualitatif, (Bandung: PT Remaja Rosdakarya) Chaplin.2011. Kamus Lengkap Psikologi. (Jakarta)

Harjani Hefni, Perkembangan Ilmu Komunikasi Islam Jurnal Komunikasi Islam, Volume 04, Nomor 02, Desember 2014

Hasan Asari.2009. Abstraksi Tesis Pascasarjana IAIN Sumatera Utara.

Imam B Jauhari, Teori Sosial, Proses Islamisasi Dalam Sistem Ilmu Pengetahuan, Pustaka Pelajar, 2012, h. 87

WJS Poerwadarminta. 2008. Kamus Besar Bahasa Indonesia (KKBI), Jakarta.

Marhaeni Fajar. 2009. Ilmu Komunikasi: Teori \& Praktik (Jakarta: Graha Ilmu)

S. Djuarsa Sendjaja, Ph.D, Pengantar Ilmu Komunikasi: Signifikasi, Konsep, dan Sejarah.

Source of Focus Grup Discussion :

Focus Grup Discussion delivered Erwan Efendi as Alumni of Islamic communication and broadcasting (27 August 2018)

Focus Grup Discussion delivered Hasrat Efendi Samosir (27 August 2018) 